\title{
Biochemical function of typical and variant Arabidopsis thaliana U-box E3 ubiquitin-protein ligases
}

\author{
Jakob WIBORG, Charlotte O'SHEA and Karen SKRIVER* ${ }^{1}$ \\ *Department of Molecular Biology, University of Copenhagen, Universitetsparken 13, \\ DK - 2100 Copenhagen Ø
}

The variance of the U-box domain in sixtyfour Arabidopsis thaliana ubiquitin-protein ligases (E3s) was used to examine the interactions between E3s and ubiquitinconjugating enzymes (E2s). E2s and E3s are components of the ubiquitin protein degradation pathway. Seven U-box proteins were analyzed for their ability to ubiquitinate proteins in vitro in cooperation with different E2s. All U-box domains exhibited ubiquitination activity and interacted productively with UBC4/5-type E2s. Three and four of the U-box domains mediated ubiquitin addition in the presence of UBC13 and UBC7 E2s, respectively, but no productive interaction was observed with the UBC15 E2 tested. The activity of AtPUB54 was dependent on $\operatorname{Trp}^{266}$ in the E2-binding cleft, and the E2 selectivity was changed by substitution of this position. The function of the distant U-box protein, AtPUB49, representing a large family of eukaryotic proteins containing a U-box linked to a cyclophilin-like peptidyl-prolyl cis-trans isomerase domain, was characterized biochemically. AtPUB49 functioned both as a prolyl isomerase and a chaperone by catalyzing cis/trans isomerization of peptidyl-prolyl bonds and dissolving protein aggregates. In conclusion, both typical and atypical Arabidopsis U-box proteins were active E3s. The overlap in the E3/E2 selectivity suggests that in vivo specificity is not determined only by the E3/E2 interactions but also by other parameters, e.g. co-existence or interactions with additional domains. The biochemical functions of AtPUB49 suggest that the protein can be involved in folding or degradation of protein substrates. Similar functions can also be retained within a protein complex with separate chaperone and Ubox proteins.

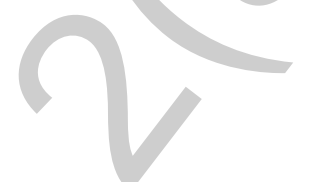

Key words: ubiquitin-conjugating E2 enzyme, cyclophilin, peptidyl-prolyl cis-trans isomerase (PPIase), chaperone, E2/E3 specificity, U-box engineering

Running title: Arabidopsis U-box proteins: variations and interactions with E2 enzymes

\footnotetext{
${ }^{1}$ To whom correspondence should be addressed (email kskriver@aki.ku.dk) Abbreviations used: ARM, armadillo; CHIP, C-terminus of Hsc70-interacting protein; CLD, Cyp-like domain; CS, citrate synthase; $\mathrm{C}_{\mathrm{T}}$, cycle threshold; Cyp, cyclophilin; E2, ubiquitin-conjugating enzyme; E3, ubiquitin-protein ligase; MBP, maltose-binding protein; PPIase, peptidyl-prolyl isomerase; PUB, Plant Ubox; Suc-AAPF-pNA, N-succinyl-Ala-Leu-Pro-Phe-p-nitroanilide; UBC, ubiquitin-conjugating enzyme
} 


\section{INTRODUCTION}

The ubiquitin proteolytic pathway plays an important role in the degradation of target proteins, many of which are short lived and have a regulatory function. In this system, the target protein is modified by attachment of a ubiquitin polymer and degraded by the $26 \mathrm{~S}$ proteasome. A ubiquitin-activating enzyme (E1) transfers ubiquitin to an ubiquitinconjugating enzyme (E2). The E2 enzyme binds ubiquitin through a cysteine residue present in the conserved ubiquitin-conjugating enzyme (UBC) domain. Formation of a covalent bond between ubiquitin and a target substrate is facilitated by an ubiquitinprotein ligase (E3) that may bind both the E2-ubiquitin complex and a specific substrate [1]. E3 protein families include proteins with a U-box domain [2]. U-box proteins may also function as E4s to mediate the assembly of polyubiquitin chains on proteins already ubiquitinated by an E3 enzyme [3]. Determination of the three-dimensional structure of the approximately 70 residues U-box domain [4-8] showed that the domain adopts the fold of the RING zinc finger domain and some form a dimer in solution [5,7,9].

Molecular chaperones recognize misfolded or unfolded proteins and contribute to their refolding. Several U-box proteins have been shown to be part of the chaperone apparatus. For example, UFD2 interacts with the AAA type ATPase Cdc48, which possesses chaperone activity, and is thought to contribute to cell survival under stressful conditions in yeast [3]. In mammalian cells, UFD2a interacts with the mammalian ortholog of Cdc48, VCP, and is implicated in the degradation of damaged proteins [10]. Denatured protein substrates were multiubiquitinated by the C-terminus of Hsc70-interacting protein (CHIP) U-box protein in vitro, but only when the unfolded substrate was captured by the chaperones Hsp90, or Hsc70 and Hsp40 [11]. Thus, CHIP may act as a co-chaperone that determines the balance between folding and degradation of proteins. Further suggestions of a link between U-box mediated protein degradation and chaperone-mediated folding come from studies showing that five mammalian U-box proteins can interact with molecular chaperones or co-chaperones [12], and from the identification of a protein, cyclophilin-60 (Cyp-60) or CYC4, containing both an U-box domain and a Cyp-like chaperone domain [2].

Cyps were originally identified as receptors for immunosuppressive drugs such as cyclosporine A, and were later found to have peptidyl-prolyl cis-trans isomerase (PPIase) or rotamase activity and to function as molecular chaperones (for review se [13]). PPIases catalyze trans/cis isomerization of proline-peptid bonds, which is often a rate-limiting step in protein folding [14], and can enhance the rate of protein folding in vivo. The relative contribution of the PPIase and chaperone activities to protein folding in vivo remains elusive [13]. The prototypical Cyp, human CypA, consists of only the highly conserved, approximately 100 amino acids long, Cyp-like domain (CLD), and is implicated in several physiological functions and diseases. For example, under normal conditions binding of the CypA PPIase active site to a regulatory proline residue in Itk, a tyrosine kinase, is important for suppression of the T helper 2 response [15], and CypA knockout mice develop an allergic disease. The large Cyps have a modular structure with functionally independent modules for example a CLD and a U-box domain [2]. 
U-box proteins are overrepresented in Arabidopsis compared with other model eukaryotes. Only two and six U-box proteins are present in yeast and animal, respectively [16]. By contrast, Arabidopsis has been predicted to contain 62 U-box proteins [5] with the majority of the proteins containing an ARMADILLO (ARM) repeat proteininteraction region in addition to the U-box domain. U-box-ARM proteins have been implicated in the regulation of cell death and defense [17-18]. Interestingly, the Pseudomonas syringae protein AvrPtoB, which inhibits immunity-associated programmed cell death in plants, is an E3 U-box protein suggesting that the pathogen Pseudomonas uses molecular mimicry to destroy plant defense [19]. U-box proteins are also involved in other important plant-specific pathways. For example, U-box proteins play a role in control of both self-incompatibility [20] and pseudo-self-incompatibility [21], and Arabidopsis CHIP functions in abiotic stress [22].

The physiological importance and structural variation of the Arabidopsis U-box proteins makes studies of their biochemical function important. We have examined the specificity of the interactions between different Arabidopsis E2s and U-box E3s based on sequence and structure information. In addition, we have demonstrated that the U-box protein AtPUB49 functions as a chaperone providing yet another link between ubiquitindependent protein degradation and chaperone-dependent protein refolding.

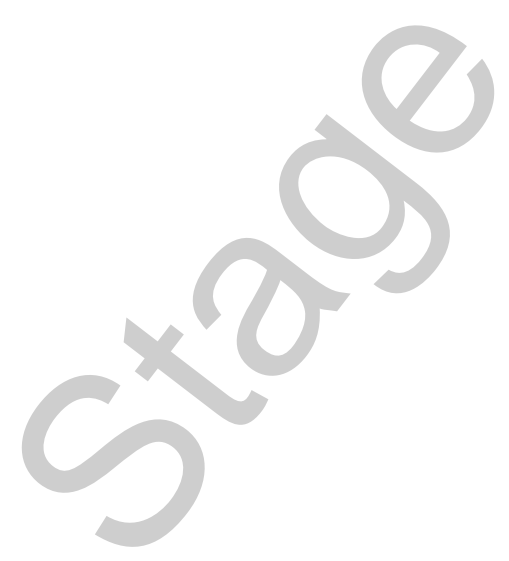




\section{MATERIALS AND METHODS Analysis of gene expression}

Expression data were collected from the Genevestigator [23-24] website (www.genevestigator.ethz.ch). Data are reported as absolute expression values and colour-coded such that for each gene the highest signal intensity obtains value $100 \%$ (dark blue) and absence of signal obtains value $0 \%$ (white).

\section{Phylogenetic analysis}

The phylogenetic analysis of U-box domain sequences was performed using MEGA4 software [25]. The input was a multiple alignment of U-box sequences generated in ClustalX. The program calculates the distances between all pairs of sequences and uses the neighbor-joining method [26] and the PAM matrix to construct the tree. The reliability of the different groupings of the tree was measured by bootstrapping.

\section{Analysis of gene expression by quantitative real-time PCR}

Quantitative real-time PCR used the Superscript III Platinum SYBR Green One-Step qRT-PCR kit (Invitrogen) with 10 pmol of each primer and 50 ng cDNA in $20 \mu \mathrm{l}$. The thermal cycling conditions used were $95^{\circ} \mathrm{C}$ for 5 min followed by 40 cycles of $95^{\circ} \mathrm{C}$ for $15 \mathrm{~s}, 57^{\circ} \mathrm{C}$ for $30 \mathrm{~s}$, and $72{ }^{\circ} \mathrm{C}$ for $30 \mathrm{~s}$, followed by a melt cycle from $65^{\circ} \mathrm{C}$ to $96^{\circ}$. The reactions were run on an Applied Biosystems 7500 Real Time PCR instrument. For making cDNA from rosette leaves, Arabidopsis plants were grown in the greenhouse at $21^{\circ} \mathrm{C}$ with $18 \mathrm{~h}$ light and $6 \mathrm{~h}$ dark. Tissues were harvested and frozen in liquid nitrogen. Total RNA was isolated by $\mathrm{LiCl}$ precipitation, phenol/chloroform extraction, and ethanol precipitation followed by DNase treatment in a reaction coupled to reverse transcription using oligo-dT primers, murine leukaemia virus reverse transcriptase (GeneAmp; Applied Biosystems), and $1 \mu \mathrm{g}$ of mRNA. Primers for real time PCR are shown in Supplementary Table 1 . The reactions were performed in triplicate, and quantification of cycle threshold $\left(\mathrm{C}_{\mathrm{T}}\right)$ values was achieved by calculating means of normalized expressions using Q-gene software [27] and the Actin2 (At3g18780) gene as reference gene for normalization. All primer pairs amplified a single product of the expected size, which was confirmed by melt-curve analysis.

\section{Generation of plasmids for protein expression}

For production of recombinant E2 and E3 proteins cDNA clones obtained from the Arabidopsis Biological Resource Center (http://www.biosci.ohiostate.edu/ plantbio/Facilities/abrc/abrchome.htm) were amplified by PCR to obtain the complete coding part of At5g62540 (UBC2) [28], At5g53300 (UBC4/5), At3g46460 (UBC7), At1g16890 (UBC13), and At5g42990 (UBC15) using the primer sets listed in Supplementary Table 2. The PCR-products were cloned into pET-15b (Novagen) for production of histidine-tagged recombinant proteins. The recombinant proteins were named to show that they contained a histidine tag (His6), their identity (e.g. At5g62540), and the type of UBC (e.g. UBC2), e.g. His6-At5g62540(UBC2). Gateway pDONR (Invitrogen) entry clones of At5g05080 (UBCE), At2g16740 (UBC4/5), At1g78870 (UBC13), At1g17280 (UBC6), and At1g63800 (UBC8) were obtained from the Arabidopsis Biological Resource Center and introduced into the destination vector pDEST17 (Invitrogen) to produce expression plasmids for production of histidine-tagged 
full-length recombinant proteins of At5g05080 (UBCE), At2g16740 (UBC4/5), At1g78870 (UBC13), and At1g63800 (UBC8), and a C-terminally truncated version lacking the predicted transmembrane region of At1g17280 (UBC6). The resulting recombinant proteins were named as described above except for recombinant At1g17280 which was named His6-At1g17280( $\Delta$ tm,UBC6) to indicate the lack of the transmembrane region from this protein.

The Plant U-box (PUB) [29] E3 proteins were produced by cloning of a PCR fragment of AtPUB14 (At3g54850; residues 249-632) [5] and AtPUB63 (At5g05230; residues 170257) into pMAL-c2 (New England Biolabs) to obtain a maltose-binding protein (MBP) fusion protein or by inserting PCR fragments of AtPUB41 (At5g62560), AtPUB54 (At1g01680), AtPUB56 (At1g01670), and AtPUB60 (At2g33340) into pENTR/D-TOPO (Invitrogen) followed by recombination into pDEST-566 (Addgene) to obtain His6-MBP fusion proteins or of AtPUB49 (At5g67530) into pENTR/D-TOPO and pDEST17 (Invitrogene) to obtain a histidine-tagged recombinant protein. The primer set used for amplification are listed in Supplementary Table 2. The resulting recombinant proteins were named: MBP-AtPUB14(249-632), MBP-AtPUB63(170-257), His6-MBP-PUB41(1559), His6-AtPUB49(1-595), His6-MBP-AtPUB54(1-308), His6-MBP-AtPUB56(1-365), and His6-MBP-AtPUB60(1-485). Substitution in His6-MBP-AtPUB54(1-308) was performed using the primers 5'GAGGAATTCAGAAAGGCGCTAAGGTCAGGAGG and 5'CCTCCTGACCTTAGCGCCTTTCTGAATTCCTC $\left(\operatorname{Trp}^{266} \rightarrow\right.$ Ala) and 5’GCAGAGGAATTCAGAAAGCATCTAAGGTCAGGAGGTCG and 5’CGACCTCCTGACCTTAGATGCTTTCTGAATTCCTCTGC $\left(\operatorname{Trp}^{266} \rightarrow\right.$ His).

\section{Purification of recombinant protein}

Escherichia coli strain BL21(DE3) was transformed with the expression constructs and used for expression of His-tagged and MBP-fusion recombinant proteins. For production of the MBP-fusion proteins transformed $E$. coli cultures were grown to a cell density of 0.6 in LB medium before induction with $0.5 \mathrm{mM}$ isopropyl-B-D-thiogalactopyranoside. After $3 \mathrm{~h}$ of incubation at $37{ }^{\circ} \mathrm{C}$ or overnight at $15^{\circ} \mathrm{C}$ the cells were harvested by centrifugation. For purification of MBP fusion proteins, the pellet was resuspended in 20 $\mathrm{mM}$ Tris-HCl, pH 7.4, $200 \mathrm{mM} \mathrm{NaCl,} 0.1$ \% Triton X-100, $0.01 \mathrm{M}$ phenylmethylsulphonyl fluoride, $1 \mathrm{mM}$ dithiothreitol, and the cells were disrupted by sonication using a Soniprep 150 (MSE) with an amplitude of 7 micron for $30 \mathrm{~s}$, paused for $30 \mathrm{~s}$, and repeated three times. The sonicate was cleared by centrifugation at $10,000 \mathrm{x}$ $\mathrm{g}$ for $20 \mathrm{~min}$ at $4^{\circ} \mathrm{C}$. The supernatant was diluted 1:5 with $20 \mathrm{mM}$ Tris-HCl, pH 7.4, 200 $\mathrm{mM} \mathrm{NaCl}$, and protein from $200 \mathrm{ml}$ E. coli culture (at the time of harvest; $\mathrm{A}_{600}$ approximately three) was bound to $2 \mathrm{ml}$ (bed vol.) amylose resin (New England Biolabs). The column was washed with 10 column volumes of $20 \mathrm{mM}$ Tris-HCl, pH 7.4, $200 \mathrm{mM}$ $\mathrm{NaCl}$, the MBP-fusion proteins were eluted in the same buffer containing $10 \mathrm{mM}$ maltose, and the buffer was changed using an Amicon Ultra-15 10,000 MWCO centrifugal filter.

For production of His-tagged proteins, the E. coli pellet was resuspended in $50 \mathrm{mM}$ sodium phosphate, $\mathrm{pH} 7.0,300 \mathrm{mM} \mathrm{NaCl}$, the cells were disrupted by sonication as described above, the sonicate was cleared by centrifugation at $10.000 \mathrm{x} g$ for $20 \mathrm{~min}$ at 4 
${ }^{\circ} \mathrm{C}$, and His-tagged protein (from $200 \mathrm{ml} \mathrm{E}$. coli culture) was bound to $2 \mathrm{ml}$ prewashed BD Talon metal-affinity resin (Clontech). The column was washed twice with 10 column volumes of $50 \mathrm{mM}$ sodium phosphate, $\mathrm{pH} 7.0,300 \mathrm{mM} \mathrm{NaCl}$, and protein eluted using $50 \mathrm{mM}$ sodium phosphate, $\mathrm{pH}$ 7.0, $300 \mathrm{mM} \mathrm{NaCl}, 150 \mathrm{mM}$ imidazole, and the buffer was changed using an Amicon Ultra-15 10,000 MWCO centrifugal filter.

\section{In Vitro ubiquitination assay}

The assays were performed essentially as described previously [5]. Reaction mixtures (30 $\mu \mathrm{l})$ contained $0.5 \mu \mathrm{g}$ of recombinant E3, $20 \mathrm{ng}$ of rabbit E1 (Boston Biochemicals), $20 \mathrm{ng}$ of recombinant E2, $10 \mu \mathrm{g}$ of $\mathrm{His}_{6}$-ubiquitin (Sigma-Aldrich), and $90 \mu \mathrm{g}$ protein from extracts of $E$. coli strain BL21(DE3) in a buffer containing $50 \mathrm{mM}$ Tris-HCl, pH 7.4, 2 $\mathrm{mM}$ ATP, $5 \mathrm{mM} \mathrm{MgCl}_{2}$, and $2 \mathrm{mM}$ dithiothreitol. For making the E. coli extracts, the cells were resuspended in the assay buffer, placed on ice, and disrupted by sonication using a Soniprep 150 (MSE) with an amplitude of 7 micron for $30 \mathrm{~s}$, paused for $30 \mathrm{~s}$, and repeated three times. The reactions were incubated for $2 \mathrm{~h}$ at $30^{\circ} \mathrm{C}$, and $1 / 6$ of the reactions (approximately $20 \mu \mathrm{g}$ ) were separated by SDS-PAGE and analyzed by Western blot analysis. The proteins were transferred to an Immobilin-P membrane (Millipore) and incubated in $3 \%(\mathrm{w} / \mathrm{v})$ dry milk in a buffer containing $10 \mathrm{mM}$ Tris-HCl, $\mathrm{pH}$ 8.0, $150 \mathrm{mM}$ $\mathrm{NaCl}, 0.1 \%(\mathrm{v} / \mathrm{v})$ Tween-20 for two hours at room temperature followed by incubation overnight at $4^{\circ} \mathrm{C}$ using a mouse monoclonal anti-ubiquitin antibody (diluted 1:500), which was conjugated to horse radish peroxidase (Santa Cruz Biotechnology). After washing, proteins were detected by enhanced chemiluminescence (GE Health Care, Life Sciences). All experiments were performed at least three times with different preparations of recombinant E2 and E3 proteins.

\section{Peptidyl-prolyl isomerase (PPIase) assay}

The PPIase activity of recombinant AtPUB49 (His6-AtPUB49(1-595) was assessed by the method of Kofron et al. [30] using the tetrapeptide substrate N-succinyl-Ala-Leu-ProPhe-p-nitroanilide (Suc-AAPF-pNA; Sigme-Aldrich). All reagents were pre-equilibrated until the temperature reached $0^{\circ} \mathrm{C}$. In a $1 \mathrm{ml}$ glass cuvette, His6-AtPUB49(1-595) at varying concentrations was mixed with $100 \mu \mathrm{l} \alpha$-chymotrypsin (Sigma-Aldrich; $60 \mathrm{mg}$ $\mathrm{ml}^{-1}$ in $1 \mathrm{mM} \mathrm{HCl}$ ), and the volume was brought up to $975 \mu \mathrm{l}$ with assay buffer $(50 \mathrm{mM}$ Hepes-KOH, $\mathrm{pH} 8.0$ at $0{ }^{\circ} \mathrm{C}, 100 \mathrm{mM} \mathrm{NaCl}$ ). The reaction was initiated by the addition of $25 \mu$ substrate ( $4 \mathrm{mM}$ tetrapeptide in $470 \mathrm{mM}$ anhydrous $\mathrm{LiCl}$ prepared in trifluoroethanol). Changes in absorbance due to released p-nitroaniline were monitored at $390 \mathrm{~nm}$ at $0{ }^{\circ} \mathrm{C}$ over a 5 min period in a Perkin Elmer Lambda $35 \mathrm{UV} / \mathrm{VIS}$ spectrophotometer with a thermo stated cuvette holder. Initial reaction rates were determined from the slope of the linear portion of the plot of $A_{390}$ against time. The enzymatic activity of each sample was calculated as the difference between the rate of catalyzed and spontanoeus reactions, and product formation was calculated from $\Delta \mathrm{A}_{390}$ using 13.3000 $\mathrm{M}^{-1} \mathrm{~cm}^{-1}$ as the molar extinction coefficient for $\mathrm{p}-$ nitroaniline [30]. The experiments were performed three times with different preparations of His6-AtPUB49(1595).

\section{Chaperone assay}


The ability of recombinant AtPUB49 to inhibit the aggregation of citrate synthase (CS) was examined according to the well described CS aggregation assay [31]. CS (SigmaAldrich) was dialyzed against TE buffer (50 mM Tris-HCl, pH 8.0, 2 mM EDTA) over night at $4{ }^{\circ} \mathrm{C}$, and concentrated using an Ultrafree-MC Centrifugal Filter Unit (Millipore). Each assay contained $2 \mu \mathrm{M}$ CS and varying amounts of His6-AtPUB49(1-595) in a total volume of $1 \mathrm{ml}$ Hepes- $\mathrm{KOH}$, $\mathrm{pH}$ 7.5. All mixtures, kept in a cuvette with magnetic stirring, were prewarmed to $43^{\circ} \mathrm{C}$ before addition of CS. After addition of CS the increase in absorbance at $360 \mathrm{~nm}$ was measured for a period of $30 \mathrm{~min}$ in a Perkin Elmer Lambda 35 UV/VIS UV-vis spectrophotometer using a thermo stated cuvette holder. The experiments were performed at three times with different preparations of His6AtPUB49(1-595).

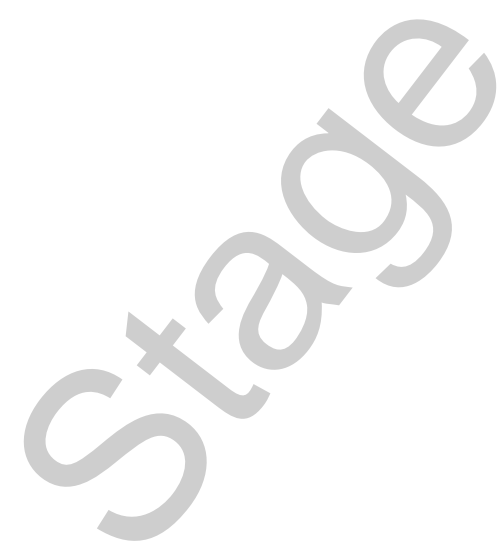




\section{RESULTS}

\section{The Arabidopsis U-box family}

BLAST homology searches identified 64 putative U-box protein, including At5g57035, At3g49065, and At5g05230, which were not included in previous compilations, and were named AtPUB61, AtPUB62, and AtPUB63, respectively [5, 29, http://www.arabidopsis.org/browse/genefamily/pub.jsp]. A phylogenetic analysis of the 64 Arabidopsis U-box proteins was performed based on an alignment limited to the Ubox domain. An unrooted tree was constructed in MEGA4 [25] using the neighborjoining method [26], and branch reliability was assessed by bootstrap analysis. The obtained Arabidopsis U-box protein phylogeny is presented Figure 1.

The Arabidopsis U-box proteins have previously been assigned to different classes based on domain structure [5,29]. Thirty four per cent of the Arabidopsis U-box proteins belong to the sub groups of ARM repeat proteins, which also include a sub group of proteins containing the plant specific UND domain (Figure 1) [32]. The different sub groups also reflect sequence variation within the highly conserved U-box domain (Figures 1 and 2A). Most of the ARM repeat and kinase proteins contain Ile, Trp, and Pro at positions corresponding to Ile ${ }^{256}$, $\operatorname{Trp}^{281}$, and Pro ${ }^{290}$ in AtPUB14, for which the tertiary structure is known [5]. These residues are present in the central $\alpha$ helix and loops L1 and L2 of the U-box domain and are part of the E2-binding cleft (Figure 2A and 2B) [4,5]. Structure analyses and mutagenesis studies suggested that these and a few additional residues (Figure 2A) are important for the interactions of the zebrafish and mouse CHIP U-box proteins with their target E2s [6,7]. When Ile ${ }^{216}\left(\mathrm{Ile}^{256}\right.$ in AtPUB14), Phe ${ }^{218}\left(\mathrm{Leu}^{258}\right.$ ), and $\operatorname{Arg}^{253}\left(\mathrm{Gln}^{293}\right)$ in zebrafish CHIP were changed to alanine, no E3 ubiquitin ligase activity was detected in vitro, and when $\mathrm{His}^{241}\left(\mathrm{Trp}^{281}\right)$ and $\mathrm{Val}^{245}\left(\mathrm{Gly}^{285}\right)$ were changed to alanine, the activity was reduced [6].

\section{Variation of the Arabidopsis $\mathrm{U}$-box sequences}

Seven proteins representing different phylogenetic branches and sequence variants were selected to examine the activity of the Arabidopsis U-box proteins and their cooperation with specific E2s. AtPUB14, AtPUB54, and AtPUB56 were selected because they contain prototypical Arabidopsis U-box domains with conserved Ile, Trp, and Pro residues (Figure 2A). AtPUB54 and AtPUB56 show a high degree of sequence similarity (78 per cent in the U-box domain) making similar E2 selectivity likely for these proteins. In Fig. 2C, a schematic representation of the domain structure of these proteins shows that AtPUB14 contains several ARM repeats and an UND domain in addition to the Ubox domain and that AtPUB54 and AtPUB56 contain a kinase domain. In addition, this study focused on the following U-box proteins: AtPUB60 which has an N-terminal Ubox domain and a WD40 repeat region in the C-terminal region of the protein and shows sequence similarity to yeast Prp19, also outside the U-box domain. AtPUB60 contains a histidine in the position corresponding to $\operatorname{Trp}^{281}$ of AtPUB14. AtPUB41, which also contains an ARM repeat region, has a variant U-box domain with a cysteine residue at the position corresponding to Trp ${ }^{281}$ of AtPUB14. In addition, AtPUB41 has a substitution at the position corresponding to Pro ${ }^{290}$ in AtPUB14. AtPUB49, which is the Arabidopsis ortholog of CYC4 [2] and contains a leucine and a tyrosine in the positions corresponding to $\mathrm{Ile}^{256}$ and $\operatorname{Trp}^{281}$ of AtPUB14. AtPUB63, which also contains atypical amino acid 
residues in the key positions. A threonine is present instead of $\mathrm{Ile}^{256}$, a valine is most likely present instead of $\operatorname{Trp}^{281}$, and no proline is found in the vicinity of $\operatorname{Pro}^{290}$ in AtPUB14.

The proteins selected represent the structural range of the Arabidopsis U-box proteins. All amino acid residues, Trp, Tyr, His, Cys, and Val, present in the key position corresponding to $\operatorname{Trp}^{281}$ of AtPUB14 are represented. In contrast, previous work on Arabidopsis U-box proteins focused on U-box proteins with a tryptophan [5,32] or a histidine [33] at this key position [34]. The six mammalian U-box proteins, which showed E2-selective in vitro ubiqutination activity, have a relatively larger variation at this position than the Arabidopsis U-box proteins [2] suggesting than the atypical Arabidopsis proteins may also be active.

\section{Expression of the AtPUB14, AtPUB41, AtPUB54, AtPUB56, AtPUB60, and AtPUB63 U-box genes}

The expression pattern of all 64 predicted Arabidopsis U-box genes was analyzed using the expression data complied for the Arabidopsis ATH1 22K microarray chip experiments [24]. The Genevestigator online search tool Meta-Analyzer reports expression as heat maps in blue/white coding (absolute signal values) for different organs and developmental stages. The genes were shown to be expressed above background levels using Digital Northern at Genevestigator (data not shown). For the U-box genes selected for this study, information was lacking for only AtPUB41 and AtPUB54. However, several cDNA clones were available for both genes showing that they are expressed.

According to analysis performed by Meta-Analyzer stress exposure did not have any significant effect on the expression of the AtPUB14, AtPUB49, AtPUB56, AtPUB60, and AtPUB63 genes (data not shown). Data on the expression of theses genes in different growth stages are reported in Figure $3 \mathrm{~A}$. For all genes, expression was detected at most stages. Some of the genes, AtPUB14, AtPUB15 (At5g42340; included for comparison), AtPUB49, and AtPUB63 were expressed to the highest level in the late growth stages, siliques. AtPUB60 showed significant, but varying, levels of expression at all stages, with highest levels detected in seedlings and siliques. The expression level in different organs was also examined (Figure 3B). AtPUB49 showed highest expression in seeds and root tip, AtPUB63 was most highly expressed in seeds, leaves, cork, and senescent leaves, and for AtPUB14 the highest expression level was in pollen. Expression of these U-box genes in many organs is in contrast to the restricted expression pattern of other U-box genes, such as AtPUB15, which was expressed almost exclusively in pollen indicative of a pollen-specific function.

The Genevestigator microarray data were compared to results obtained from quantitative real-time PCR using E3 gene specific primers. cDNA synthesized from RNA isolated from rosette leaves, in which the E3 and E2 gene expression varied significantly, was used for the comparison (Figure 3C). In general, the results obtained by this method were in accordance with the Genevestigator microarray data (stage four from the left in Figure 3A). The AtPUB14, AtPUB15, AtPUB63, AtPUB41, AtPUB54, and AtPUB56 genes were 
expressed at low levels, whereas AtPUB60 was expressed at a much higher level corresponding to approximately 3600 times that of the AtPUB15 gene.

\section{Arabidopsis E2s - sequence variation and gene expression}

To be active in ubiquitination, E3s need to cooperate with an E2. The distinction of different families of E2s that are conserved across phyla was evident from a phylogenetic analysis [35]. However, since more UBCs exist in Arabidopsis than in yeast (37 vs. 11), it is not possible to find a yeast ortholog for all Arabidopsis E2s [28,36]. To avoid confusion, the E2s are referred to by their genomic loci (e.g. At2g62540) followed by a parenthesis showing the UBC sub family to which they were assigned. For example, At2g62540(UBC2) shows that this E2 is most closely related to yeast UBC2. Nine E2s, covering the different UBC families and phylogenetic range [37], were selected for the assays. A few sub-groups were not represented, either because their members showed no ubiquitination activity or were insoluble when produced as recombinant proteins [36]. The E2s selected were: At2g62540(UBC2), At5g53300(UBC4/5), At2g16740(UBC4/5), At1g17280(UBC6), At3g46460(UBC7), At1g63800(UBC8), At1g16890(UBC13), At1g78870(UBC13), At2g42990(UBC15), and At5g05080(UBCE). Two family 4/5 and 13 UBCs were included to examine if the U-box proteins discriminate between closely related E2s.

The temporal expression pattern of the E2 genes is shown in Figure 3A. No data were available for AtUBC1g16890(UBC13). At1g78870(UBC13) was expressed at high levels at all times examined, and At1g17280(UBC6), At3g46460(UBC7), At1g63800(UBC8), and $A t 5 g 05080(U B C E)$ were also expressed ubiquitously at significant levels. At2g42990(UBC15) was expressed at low levels, except in the late flowering stages. Examination of the organ specific/spatial expression pattern (Figure 3B) revealed that At2g42990(UBC15) was expressed specifically in petals. At1g63800(UBC8) showed higher expression levels in cauline and senescent leaves than in other organs. Significant, but varied expression, of At2g16740(UBC4/5) is in accordance with previous expression analyses of the gene [36]. The expression of the E2 genes in rosette leaves was also analyzed using quantitative real-time PCR (Fig. 3C). Again the PCR data were generally consistent with the microarray data and showed relatively high levels of expression for most of the E2 genes, with the At5g53300(UBC4/5) gene showing the highest level of expression . In conclusion, most of the E2s genes examined are abundantly expressed, except At2g42990(UBC15), which seems to be expressed specifically in flower tissue.

\section{Activity of prototypical and variant Arabidopsis U-box proteins}

The E3 proteins tested for ubiquitination activity were produced as recombinant proteins. Five of the proteins, AtPUB41, AtPUB49, AtPUB54, AtPUB56, and AtPUB60, were produced as the full length recombinant protein fused to an $\mathrm{N}$-terminal histidine (AtPUB49) or His6-MBP tag. In the case of AtPUB14, only a fragment containing the Ubox and the ARM repeat domain was produced as a fusion to MBP due to solubility problems with the full length protein [5]. It was also impossible to produce AtPUB63 as a full-length protein. Therefore, a fragment consisting of residues 170-257 from AtPUB63 fused to MBP was used for the assays. All E2s used were produced as full-length recombinant proteins containing an $\mathrm{N}$-terminal histidine tag, except in the case of 
At1g17280, which was produced as the recombinant protein lacking the predicted trans membrane region.

Yield, size, and quality of the affinity purified recombinant proteins were examined by absorption spectroscopy and SDS-PAGE (Figure 4A and B). Approximately $20 \mathrm{mg}$ affinity purified E2 recombinant protein was obtained from $1 \mathrm{l}$ E. coli culture harvested at an $A_{600}$ value of approximately three, except in the case of His6-At1g16890(UBC13), for which only approximately $5 \mathrm{mg}$ was obtained. The yield of the His6-MBP tagged fulllength PUB proteins and His6-AtPUB49(1-595) was approximately $10 \mathrm{mg}$ pr. 1 E. coli culture, whereas the comparable yield of the largest recombinant protein produced, His6MBP-AtPUB41(1-559), was only about $5 \mathrm{mg}$. Analysis by SDS-PAGE showed that the molecular mass values of the purified recombinant proteins were in accordance with the calculated mass values within the experimental errors expected for SDS-PAGE (Figure 4A and B, Supplementary Table 2). In the case of His6-At1g63800 and His6-At1g17280, which migrated slower than expected from the calculated molecular mass values, matrixassisted laser desorption/ionization time-of-flight mass spectrometry confirmed the expected mass for the recombinant proteins (data not shown). In general, the purified proteins had only minor protein contaminations. For example, a contaminating protein with a molecular mass of approximately $43 \mathrm{kDa}$, the expected size of $\mathrm{MBP}$, was present together with several of the purified MBP fusion proteins (Figure 4B).

For the in vitro ubiquitination assays, the E3 indicated was incubated with ubiquitin, rabbit E1, and the E2 as specified, and ubiquitin chain formation was monitored. Potential substrates included the added recombinant proteins and bacterial proteins. The reactions were probed by Western blotting using anti-ubiquitin for the detection. Initially, assays without an E3 were performed to examine if the E3-independent activity of each E2 was too pronounced to monitor E3-dependence in the assays. His6At5g05080(UBCE), His6-At1g63800(UBC8), and His6-At5g62540(UBC2) transferred ubiquitin to proteins dependent upon an E1, but independent of an E3 ubiquitin ligase (Figure 5A). Therefore, these proteins were not included in the rest of the assays.

AtPUB54 and AtPUB56 contain prototypical Arabidopsis U-box domains. When either of these was included in the assays, an ubiquitination ladder was seen with both family 4/5 UBCs and both family 13 UBCs (Figure 5B and C). Some activity was also detected with UBC6 and 7, but no activity was detected in the absence of an E2 enzyme. No significant differences were detected between the two proteins, as expected from their high degree of sequence similarity. Some of the ubiquitinated species detected were relatively small suggesting that they were derived from bacterial proteins, E2s, or partly degraded recombinant proteins or that the ubiquitin chains are of limited size or not anchored to a protein [38].

Since the position corresponding to $\operatorname{Trp}^{266}$ in AtPUB54 (Trp ${ }^{281}$ in AtPUB14) has been suggested to be of special significance for the functionality of the E2/E3 interactions $[5,34]$ this residue was changed by site-directed mutagenesis in AtPUB54 to a histidine, which is present in other U-box proteins (Figure 2A) or an alanine, which has not been identified in this position of any of the U-box domains. The amount of protein obtained 
by expression and purification was similar for wild-type and mutant His6-MBPAtPUB54(1-308). The activity of wild type and mutant His6-MBP-AtPUB54(1-308) was compared using the two UBC4/5 proteins (At2g16740 and At5g53300), and the two UBC13 proteins (At1g78870 and At1g16890) as E2. No activity was detected with His6MBP-AtPUB54(1-308, $\operatorname{Trp}^{266} \rightarrow$ Ala) using the four recombinant E2 proteins demonstrating the importance of $\operatorname{Trp}^{266}$ for the functionality of AtPUB54 (Figure 5D, lanes 1-2, 4-5,7-8,10-11). In contrast, the substitution in His6-MBP-AtPUB54(1-308, $\operatorname{Trp}^{266} \rightarrow$ His) had E2-dependent effects on the activity. Whereas the mutation resulted in a decrease or no significant change in activity with His6-At2g16740-UBC4/5 and His6At5g53300-UBC4/5 E2, respectively (Figure 5D, lanes1,3 and 4,6) no detectable activity was measured with the two UBC13 recombinant E2 enzymes, His6-At1g78870 and His6At16890 (Figure 5D, lanes 7,9 and 10,12). Since shorter exposure times showed that there was no significant difference between the signals obtained for the reactions between His6-MBP-AtPUB54 (wild type) and His6-At2g16740-UBC4/5, His6-At5g53300UBC4/5, and His6-At1g78870(UBC13), respectively (data not shown), this differential effect on the signal could not be explained by limitations of the detection system. Thus, the selectivity of His6-MBP-AtPUB54(1-308) for the E2s was changed by the $\operatorname{Trp}^{266} \rightarrow$ His substitution.

AtPUB14 has previously been shown to be active with the human UBC4/5 protein UBC5b [5]. The E2-dependent activity with family UBC4/5 E2s was confirmed, since AtPUB14 showed ubiquitination activity with both Arabidopsis UBC4/5s tested (Figure 5E). However, in contrast to the other prototypical Arbidopsis U-box proteins examined, AtPUB54 and AtPUB56, no activity was detected with the UBC13 E2s demonstrating biochemical selectivity of the different prototypical Arabidopsis U-box E3s.

The more distantly related U-Box protein AtPUB41 contains a cysteine in the position corresponding to $\operatorname{Trp}^{281}$ of AtPUB14 and does not have a proline corresponding to the structurally important proline (Pro ${ }^{290}$ in AtPUB14) [4]. Despite these atypical characteristics, recombinant AtPUB41showed activity, although only with type 4/5 UBCs (Fig. 5F). A similar restricted activity pattern was detected for another atypical Arabidopsis E3, AtPUB60, which contains a histidine in position 281. In this case the recombinant protein, His6-MBP-AtPUB60(1-537) also showed activity with the two type 4/5 E2s (Fig. 5G). AtPUB63, which was omitted from the initial reports of Arabidopsis U-box proteins, because of its relatively low degree of sequence similarity to other U-box domains and the presence of atypical amino acid residues in the U-box (Figure 1), was also able to mediate ubiquitination in the presence of both type 4/5 E2s and the UBC6 and 7 proteins included in the assays (Fig. 5H). The last atypical Arabidopsis U-box protein examined, AtPUB49, also showed activity with the two UBC4/5 E2s, but in addition it mediated ubiquitination with the recombinant UBC13 proteins, especially His6-At1g16890 (Fig. 5I).

\section{AtPUB49 belongs to the family of $U$-box/cyclophilin-like proteins}

The $65 \mathrm{kDa}$ predicted AtPUB49 protein contains two recognizable domains, an Nterminal U-box domain and a C-terminal CLD (Figure 2C) and belong to the cyclophilin protein family. Twenty nine cyclophilins were predicted to exist in Arabidopsis in a study 
in which AtPUB49 was named AtCYP65 [39]. Homology searches and domain architecture analysis showed that proteins with the U-box/cyclophilin-like domain combination are highly proliferated in eukaryotic organisms with orthologs found from fungi to mammals.

\section{AtPUB49 is a peptidyl-prolyl isomerase}

Structure based mutagenesis has pinpointed seven residues of importance to PPIase activity with the mutations $\mathrm{Arg}^{55} \rightarrow$ Ala, $\mathrm{Phe}^{60} \rightarrow$ Ala, and His ${ }^{126} \rightarrow$ Gln in human CypA showing the most severe loss in catalytic efficiencies (Figure 6) [40]. All except one of these seven residues are conserved in AtPUB49 suggesting that this protein is also a PPIase. The chymotrypsin-coupled assay with Suc-AAPF-pNA as substrate was used to examine if AtPUB49 has PPIase activity [30]. The assay is based on the ability of PPIases to catalyze conversion of the cis conformation to the trans conformation of the substrate, which can then be cleaved by chymotrypsin resulting in the formation of the colored product measured as an increase in absorbance at $390 \mathrm{~nm}$ due to PPIase activity. Increasing concentration of recombinant AtPUB49, His6-AtPUB49(1-595), resulted in increasing activity (Fig. 7). In contrast, increasing the amount of His6-MBP-PUB41(1559) did not result in significant changes of the absorbance (data not shown). The activity of His6-AtPUB49(1-595), measured as the formation of p-nitroaniline and determined from the plot of the reaction rate against the concentration of His6-AtPUB49(1-595) (Fig. 6 , insert), was $4.4 \mu \mathrm{mol} \cdot \mathrm{min}^{-1} \cdot \mathrm{mg}^{-1}$.

\section{AtPUB49 has chaperone activity}

Large PPIases also display chaperone activity in vitro in a manner that is independent of the PPIase function [13]. Molecular chaperones promote proper protein folding and prevent aggregation. Here we have examined the ability of His6-AtPUB49(1-595) to inhibit the aggregation of CS in the well described CS aggregation assay [31]. At $43^{\circ} \mathrm{C}$, CS aggregates within 10 min (Figure 8). At this temperature a 1.5 times molar excess of His6-AtPUB49(1-595) compared to CS resulted in a marked reduction of CS aggregation, and aggregation was further decreased with a further increase in the concentration of recombinant AtPUB49. A 6 fold molar excess of His6-AtPUB49(1-595) almost completely hindered aggregation (Figure 8), and no further decrease in the degree of aggregation could be detected using this assay. A similar excess of glutathione-Stransferase had no influence on the thermal aggregation of CS. This clearly demonstrated that recombinant AtPUB49 has chaperone activity.

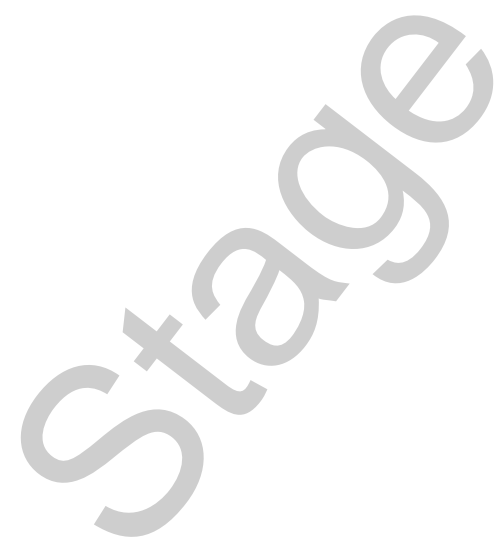




\section{DISCUSSION}

We have used the variance of the Arabidopsis U-box sequences to address function of Ubox domains and specificity of E2/E3 U-box interactions. The seven Arabidopsis U-box proteins examined were functional in ubiquitination assays despite the presence of atypical amino acid residues in key U-box positions in some of the proteins. Selectivity was detected in the cooperation of the E3s with E2s, but surprisingly all E3s examined were active with the two type 4/5 E2s used.

The amino acid residue corresponding to $\operatorname{Trp}^{281}$ in AtPUB14 (Figure 2B) is part of the hydrophobic E2-binding groove and has been suggested to be a specificity determinant for functional interactions with E2s [5,34]. However, this study showed that tryptophan, histidine, cysteine, and valine in this position all allow functional interactions with UBC4/5 E2s, demonstrating that this alone does not determine selectivity for E2s. The function of this position was examined further by mutagenesis. Substitution of $\operatorname{Trp}^{266}$ in AtPUB54 with an alanine resulted in a protein with no detectable activity with the UBC4/5 and UBC13 E2s tested, verifying the functional importance of this residue. Substitution with a histidine had different effects on the activity with the two UBC4/5 E2s examined and totally eliminated activity with the UBC13 E2s. This is interesting, both because it highlights the complicated nature of the E2/E3 interactions and because it demonstrates the possibility of changing the selectivity of the E3 for the E2s making rational engineering of E3 proteins possible.

Isoleucine $^{256}$ in AtPUB14 is also part of the E2-binding groove (Figure 2B), and most Arabidopsis U-box domains contain an isoleucine or a leucine in this position. Leucine is also compatible with activity as shown from analysis of AtPUB49 (Figure 2A and 5). AtPUB63 has a chemically different threonine, but the ubiquitination ability of AtPUB63 showed that a hydrophilic residue also allows activity. Thus, compensating interactions must take place between the atypical AtPUB63 U-box domain and the E2s. The identity of additional residues has been shown to be of importance for U-box activity. However, functionally important $\mathrm{Phe}^{218}, \mathrm{Arg}^{253}$, and $\mathrm{Val}^{245}$ in zebrafish CHIP (Leu ${ }^{258}, \mathrm{Gln}^{293}$, and $\mathrm{Gly}^{285}$ in AtPUB14) [6] are not conserved and can be a glycine in active Arabidopsis Ubox domains (Figure 2A). Even more striking, Pro ${ }^{290}$ in AtPUB14 represents a highly conserved amino acid residue and mutation of this position in Prp19 to an alanine resulted in disruption of the U-box structure [4]. The functional U-box domains in AtPUB41 and AtPUB63 lack a corresponding proline. In conclusion, U-box domains can be active in ubiquitination even though they contain underrepresented amino acids in specific positions of functional importance.

The promiscuous behavior of the two Arabidopsis UBC4/5 E2s can be explained by results from recent studies using NMR spectroscopy [41]. It was shown that UBCH5 binds ubiquitin noncovalently on a surface distinct from the active site that binds ubiquitin covalently. This may allow UBCH5-ubiquitin complexes to self-assemble promoting formation of polyubiquitin chains. This ability was dependent on $\mathrm{Ser}^{22}$ in $\mathrm{UBCH} 5$ and is specific for UBC4/5 and a few additional E2s [41-42]. Seven out of the ten Arabidopsis UBC4/5 enzymes contain a corresponding serine residue making noncovalent binding of ubiquitin a possibility for these E2s. Such interactions may 
explain the promiscuous and productive interaction of His $_{6}$-At5g53300(UBC4/5) and His $_{6}$-At2g16740(UBC4/5) with all E3s examined. This ability of the UBC4/5 enzymes results in very strong signals in biochemical ubiquitination assays and may to some extent hinder the identification of biologically relevant E2/E3 pairs using biochemical approaches to study E2/E3 specificity.

Arabidopsis has the largest known U-box family suggesting that Arabidopsis U-box proteins are involved in a diverse array of functions and are functionally redundant. Most Arabidopsis U-box proteins contain domains in addition to the U-box domain. This study showed that a member of the U-box/Cyp protein family, AtPUB49, displays peptidylprolyl cis-trans isomerase and chaperone activity. Even though the in vivo function of AtPUB49 is not known it possible that both activities contribute to proper folding of large proline-containing proteins. The gene expression analyses (Fig. 3) showed that the AtPUB49 gene is expressed in different tissues and development stages suggesting that the protein has a basic physiological function. Orthologs of AtPUB49 are highly proliferated in eukaryotic phyla suggesting that the function is important to eukaryotic life. Since yeast does not have a U-box/Cyp ortholog, the function may be related to multi cellular life. Only one members of the U-box/Cyp family has been characterized previously. Human Cyp-60, also known as CYC4, interacts with the proteinase inhibitor eglin c and exhibits E3 activity [2,43]. It has been suggested that CYC4 functions as a chaperone escorting CD147 to the cell surface [44]. In any event, interesting biological functions are to be expected for the U-box/Cyp proteins.

The function of the U-box/Cyp proteins remains unknown. However, the presence of both a cyclophilin and a U-box domain in these proteins suggest that they play a role in both folding/refolding and regulated protein degradation. It is likely that they can recognize misfolded or unfolded proteins and promote their conversion to a functional conformation and prevent protein aggregation. The ubiquitin-proteasome system on the other hand mediates destruction of misfolded or destroyed proteins. Ubiquitin may function in either proteasomal degradation, signal transduction or endocytosis, depending on the identity of the cross-linked lysine in ubiquitin [45]. However, the dependence of CYC4 on Lys ${ }^{48}$ in ubiquitin for polyubiquitination suggests that U-box/Cyps function in proteasomal degradation. In the U-box/Cyp proteins, two apparently antagonistic systems may be combined to regulate the balance between protein folding and degradation. In other cases, similar functions are performed by two separate proteins in a complex. The U-box protein CHIP can ubiquitinate denatured protein substrate in vitro, but only when the unfolded substrate is bound by Hsp90, or Hsc70 and Hsp40 [46]. Thus, CHIP can be regarded a quality control E3 that selectively ubiquitinates unfolded proteins by inter molecular collaboration with a chaperone. That functional cooperation between U-box E3s and chaperones most likely expand beyond the CHIP/Hsc and U-box/Cyp proteins as suggested by studies showing that most mammalian U-box proteins interact with molecular chaperones [12].

Since there are many more RING and U-box E3s in Arabidopsis (approximately 450 RING and 64 U-box domain proteins) [5,47] than E2s (approximately 37) [28] some E2s must interact with several E3s, as seen in this study. It is also clear from the biochemical 
studies that some E3s interact with several E2s suggesting a two way biochemical promiscuity. E2/E3 interactions may also be subject to regulation determined by temporal and/or spatial regulation of E2/E3 gene expression and protein localization. The wide expression of the E2 genes (Fig. 3) makes several of the E2 enzymes putative in vivo interaction partners of the E3 proteins examined and is in accordance with the need of some E2 enzymes to interact with several E3 proteins. Several E3 genes were expressed to the highest level in siliques (Fig. 3A), in contrast to the E2 genes examined. Likewise, the tissue-dependent expression patterns (Fig. 3B) did not reveal obvious E2/E3 pairs. Whereas AtPUB14(At3g54850) was expressed predominantly in pollen, none of the E2 genes showed pollen-specific expression. At2g42990(UBC15) is expressed specifically in petals, and no activity was detected for His6-At2g42990(UBC15) suggesting that the protein has narrow E3-specificity. Interactions between E2s and E3s may also involve other E3 domains than the U-box as suggested by the model of the Ufd2p/E2 complex [8]. Further studies are needed to address in vivo E2/E3 specificity and the physiological roles of the U-box/Cyp proteins which based on the biochemical results presented here are likely to play important regulatory roles in vivo.

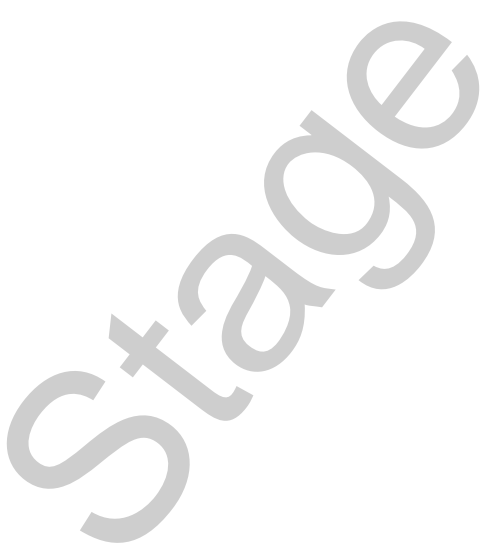


This work was supported by funds from The Danish Research Agencies (21-04-0483 and 23-04-0173). Drs. Klaus Pedersen and Michael Krogh Jensen are thanked for help with real-time PCR, Kristine Steen Jensen and Dr. Bent Sigurskjold for helpful discussions, and Michael Nielsen for technical help. 


\section{REFERENCES}

1. Pickart, C.M. (2001) Mechanisms underlying ubiquitination. Annu. Rev. Biochem. 70, 503-533

2. Hatakeyama, S., Yada, M., Matsumoto, M., Ishida, N. and Nakayama, K. I. (2001) U Box Proteins as a new Family of Ubiquitin-protein Ligases. J. Biol. Chem. 276, 33111-33120

3. Koegl, T., Hoppe, S., Schlenker, H., Ulrich, T., Mayer, S. and Jentsch, S. (1999) A Novel Ubiquitination Factor, E4, Is Involved in Multiubiquitin Chain Assembly. Cell 96, 635-644

4. Ohi, M.D., Kooi, C.W., Rosenberg, J.A., Chazin, W.J. and Gould, K.L. (2003) Structural insights into the U-box, a domain associated with multi-ubiquitination. Struc. Biol. 10, 250 - 255

5. Andersen, P., Kragelund, B.B., Olsen, A.N., Larsen, F.H., Chua, N.-H., Poulsen, F.M. and Skriver, K. (2004) Structure and Biochemical Function of a Prototypical Arabidopsis U-box Domain J. Biol. Chem. 279, 40053-40061

6. Xu, Z., Devlin, K.I., Ford, M.G., Nix, J.C., Qin, J. and Misra, S. (2006) Structure and Interactions of the helical and U-box Domains of CHIP, the C Terminus of HSP70 Interacting proteins. Biochem. 45, 4749-4759

7. Zhang, M., Windheim, M., Mark Roe, S., Peggie, M., Cohen, P., Prodromou, C. and Pearl, L.H. (2005) Chaperoned Ubiquitylation-Crystal Structures of the CHIP U Box E3 Ubiquitin Ligase and a CHIP-Ubc13-Uev1a Complex Mol Cell 20, 525-538 8. Tu, D., Ye, Y. and Brunger, A.T. (2007) Structure and function of the yeast Ubox-caontaining ubiquitin ligase Ufd2p. Proc. Natl. Acad. Sci. U.S.A. 104, 15599-15606 9. Vander Kooi, C.W., Ohi, M.D., Rosenberg, J.A., Oldham, M.L., Newcomer, M.E., Gould, K.L. and Chazin, W.J.(2006) The Prp19 U-box crystal structure suggests a common dimeric architecture for a class of oligomeric E3 ubiquitin ligases. Biochem. 45, 121-130

10. Kaneko, C., Hatakeyama, S. Matsumoto, M., Yada, M., Nakayama, K. and Nakayama, K.I. (2003) Characterization of the mouse gene for the U-box-type ubiquitin ligase UFD2a Biochem. Biophys. Res. Comm. 300, 297-304

11. Murata, S., Minami, Y., Minami, M., Chiba, T. and Tanaka, K. (2001) CHIP is a chaperone-dependent E3 ligase that ubiquitylates unfolded protein. EMBO Rep. 2, 11331138

12. Hatakeyama, S., Matsumoto, M., Yada, M. and Nakayama, KI (2004) Interaction of U-box-type ubiquitin-protein ligases (E3s) with molecular chaperones Genes Cells 9, $533-548$

13. Barik, S (2006) Immonophilins: for the love of proteins. Cell Mol Life Sci Birkhauser Verlag, Basel 1-12

14. Schmid, F.X., Mayr, L.M., Mücke, M. and Schönbrunner, E.R. (1993) Prolyl isomerases: role in protein folding. Adv. Protein Chem. 44, 25-66

15. Colgan, J, Asmal, M., Neagu, M., Yu, B., Schneidkraut, J., Lee, Y., Sokolskaja, E., Andreotti, A. and Luban J. (2004) Cyclophilin A regulates TCR signal strength in CD4+ T cells via a proline-directed conformational switch in Itk. Immunity 21, 189-201 16. Cyr, D. M., Hohfeld, J. and Patterson, C. (2002) Trends Biochem. Sci. 27, 368375 
17. Yang, C.-W., González-Lamothe, R., Ewan, R.A., Rowland,O., Yoshioka, H., Shenton, M., Ye, H., O'Donnell, E., Jones, J.D.G. and Sadanandom, A. (2006) The E3 Ubiquitin Ligase Activity of Arabidopsis PLANT U-BOX17 and Its Functional Tobacco Homolog ACRE276 Are Required for Cell Death and Defense. Plant Cell 18, 1084-1098 18. González-Lamothe, R., Tsitsigiannis, D.I., Ludwig, A.A., Panicot, M., Shirasu, K. and Jones, J.D.G. (2006) Plant Cell The U-box protein CMPG1 is required for efficient activation of defense mechanisms triggered by multiple resistance genes in tobacco and tomato. 18, 1067-83.

19. Janjusevic, R., Abramovitch, R.B., Martin, G.B. and Stebbin, C.E.(2006) A Bacterial Inhibitor of Host Programmed Cell Death Defenses Is an E3 Ubiquitin Ligase Science 311, 222 - 226

20. Stone, S.L., Anderson, E.M., Mullen, R.T. and Goring, D.R. (2003) ARC1 Is an E3 Ubiquitin Ligase and Promotes the Ubiquitination of Proteins during the Rejection of Self-Incompatible Brassica Pollen. Plant Cell 15, 885-898

21. Liu, P., Sherman-Broyles, S. and Nasrallah, M.E. (2007) A cryptic modifier causing transient self-incompatibility in Arabidopsis thaliana. Curr Biol. 17, 734-740

22. Yan, J., Wang, J., Li, Q., Hwang, J.R., Patterson, C. and Zhang, H. (2003)

AtCHIP, a U-Box-Containing E3 Ubiquitin Ligase, Plays a Critical Role in Temperature Stress Tolerance in Arabidopsis Plant Physiol. 132, 861-869

23. Zimmermann, P., Hirsch-Hoffmann, M., Hennig, L. and Gruissem, W. (2004) GENEVESTIGATOR. Arabidopsis Microarray Database and Analysis Toolbox. Plant Phys. 136, 2621-2632

24. Zimmermann, P., Hennig, L. and Gruissem, W. Gene-expression analysis and network discovery using Genevestigator. (2005) Trends Plant Sci. 10, 407-409

25. Tamura, K., Dudley, J., Nei, M. and Kumar, S. (2007) MEGA4: Molecular Evolutionary Genetics Analysis (MEGA) Software Version 4.0. (2007) Mol. Biol. Evol. 24, 1596-1599

26. Saitou, N. and Nei, M. (1987) The neighbor-joining method: a new metod for reconstructing phylogenetic trees. Mol. Biol. Evol. 4, 406-425

27. Muller, P.Y., Janovjak, H., Miserez, A.R. and Dobbie, Z. (2002) Processing of Gene Expression Data Generated by Quantitative real-Time RT-PCR. BioTechniques 32, 1372-1379

28. Bachmair, A., Novetchkova, M., Potuschak, T. and Eisenhaber, F. (2001) Ubiquitylation in plants: a post-genomic look at a post-translational modification. Trends Plant Sci. 6, 463-470

29. Azevedo, C., João Santos-Rosa, M. and Shirasu, K. (2001) The U-box protein family in plants Trends Plant Sci. 6, 354-358

30. Kofron, J.L., Kuzmic, P., Kishore, V., Colon-Bonilla, E. and Rich, D.H. (1991) Determination of Kinetic Constants for peptidyl prolyl Cis-Trans Isomerases by an Improved Spectrophotometric Assay. Biochem. 30, 6127-6134 31. Buchner, J., Grallert, H. and Jakob, U. (1998) Analysis of chaperone function using citrate synthase as nonnative substrate protein. Methods Enzymol. 290, 323-328 32. Mudgil, Y., Shiu, S.-H., Stone, S.L., Salt, J.N., and Goring, D.R. (2004) A Large Complement of the Predicted Arabidopsis ARM Repeat Proteins Are Members of the UBox E3 Ubiquitin Ligase Family. Plant Physiol. 134, 59-66 
33. Shen, G., Yan, J., Pasapula, V., Luo, J., He, C., Clarke, A.K. and Zhang, H. (2007) The chloroplast protease subunit ClpP4 is a substrate of the E3 ligase AtCHIP and plays an important role in chloroplast function. Plant J. 49, 228-237

34. Zheng, N., Wang, P., Jeffrey, P.D., Pavletich, N.P. (2000) Structure of a c-CblUbcH7 complex: RING domain function in ubiquitin-protein ligases. Cell 102, 533-539 35. Hass, A.L. and Siepmann, T.J. (1997) Pathways of ubiquitin conjugation. FASEB J. 11, 1257-1268

36. Kraft, E., Stone, S.L., Ma, L., Su, Y., Gao, Y., Lau, O.-S., Deng, X.-W., and Callis, J. (2005) Genome Analysis and Functional Characterization of the E2 and RINGType E3 Ligase Ubiquitination Enzymes of Arabidopsis. Plant Phys. 139, 1597-1611 37. Crique, M.C., de Almeida Engler, J., Camasses, A., Capron, A. and Parmentier, Y. (2002) Molecular characterization of plant ubiquitin-conjugating enzymes belonging to the UbcP4/E2-C/UBCx/UbcH10 gene family. Plant Physiol. 130, 1230-1240

38. Windheim, M., Peggie, M. and Cohen, P. (2008) Two different classes of E2 ubiquitin-conjugating enzymes are required for the mono-ubiquitination of proteins and elongation by polyubiquitin chains with a specific topology. Biochem. J. 409, 723-729 39. He, Z., Li, L. and Luan, S (2004) Immunophilins and Parvulins. Superfamily of Peptidyl Prolyl Isomerases in Arabidopsis. Plant Phys. 134, 1248-1267

40. Zydowsky, L.D., Etzkorn, F.A., Chang, H.Y., Ferguson, S.B., Stolz, L.A., Ho, S.I. and Walsh, C.T. (1992) Active site mutants of human cyclophilin A separate peptidylprolyl isomerase activity from cyclosporin A binding and calcineurin inhibition. Protein Sci. 1, 1092-1099

41. Brzovic, P.S., Lissounov, A., Christensen, D.E., Hoyt, D.W. and Klevit, R.E. (2006) A UbcH5/Ubiquitin Noncovalent Complex Is required for processive BRCA1Directed Ubiquitination. Molecular Cell 21, 873-880

42. Brzovic, P.S. and Klevit, R.E. (2006) Ubiquitin Transer from the E2 Perspective. Why is UbcH5 so promiscuous? Cell Cycle 5, 2867-2873

43. Wang, B.B., Hayenga, K.J., Payan, D.G. and Fisher, J.M. (1996) Identification of a nuclear-specific cyclophilin which interacts with the proteinase inhibitor eglin c.

Biochem. J. 14, 313-319

44. Pushkarsky, T., Yurchenko, V., Vanpouille, C., Brichacek, B., Vaisman, I., Hatakeyama, S., Nakayama, K.I., Sherry, B. and Bukrinsky, M.I. (2005) Cell surface expression of CD147/EMMPRIN is regulated by cyclophilin 60. J. Biol. Chem. 280, 27866-27871

45. Peng, J., Schwartz, D., Elias, J.E., Thoreen, C.C., Cheng, D., Marsischky, G., Roelofs, J., Finley, D. and Gygi, S.P. (2003) A proteomics approach to understanding protein ubiquitination. Nat. Biotechnol. 21, 921-926

46. Murata, S., Minami, Y., Minami, M., Chiba, T. and Tanaka, K. (2001) CHIP is a chaperone-dependent E3 ligase that ubiquitylates unfolded protein. EMBO Rep. 2, 11331138

47. Greve, K., La Cour, T., Jensen, M.K., Poulsen, F.M. and Skriver, K. (2003)

Interactions between plant RING-H2 and plant-specific NAC (NAM/ATAF1/2/CUC2) proteins: RING-H2 molecular specificity and cellular localization.

Biochem J. 371, 97-108 
Figure 1 Phylogeny of the Arabidopsis U-box proteins, unrooted tree

The analysis is based on the sequence of U-box domains and the tree was constructed in MEGA4 [25] using the neighbor-joining method [26]. The Arabidopsis proteins were named as suggested previously [27, http://www.arabidopsis.org/browse/genefamily/ pub.jsp], except for At5g57035, At3g49065, and At5g05230, which were named AtPUB61, AtPUB62, and AtPUB63, respectively. A break in the branches of the tree indicates that they have been shortened compared to the real size. Clustered groups of kinases, ARM repeat proteins, and UND/ARM repeat proteins are indicated.

\section{Figure 2 Sequence alignment of U-box domains}

(A) Alignment of the sequence of five typical Arabidopsis U-box domains (from AtPUB14, AtPUB54, AtPUB56, AtPUB10, and AtPUB45) containing an isoleucine, a tryptophan, and a proline at positions 256, 281, and 290 of AtPUB14 with the sequence of five variant Arabidopsis U-box domains (from AtPUB49, AtPUB60, AtPUB41, AtPUB63, and AtCHIP), and the U-box domain of zebrafish (Dr) CHIP, mouse (Mn) CHIP, and yeast (Sc) Prp19p. For the Arabidopsis sequences the genomic loci are shown in addition to the AtPUB names. * shows residues which have been suggested to be of importance for the interaction between U-box domains and E2 ubiquitin conjugating enzymes [6,7]. The upper line shows the position of secondary structures in AtPUB14 [5]. (B) The structure of the U-box domain of AtPUB49(249-321) [5] (accession code $1 \mathrm{~T} 1 \mathrm{H})$ is shown in ribbon format with positions corresponding to residues of importance for the E2 interaction of zebrafish CHIP highlighted in blue [6]. (C) Domain composition [5] of the predicted U-box proteins AtPUB14, AtPUB41, AtPUB49, AtPUB54, AtPUB56, AtPUB60, and AtPUB63 analyzed in this study. The UND domain was defined by Mudgil [32]. The figure is not drawn to scale.

Figure 3 Expression of Arabidopsis E3 (U-box) and E2 (UBC) genes

(A) Summary of Genevestigator ATH1 22K array data for selected Arabidopsis genes encoding U-box E3 proteins and E2 proteins. The gene-level profiles were normalized for coloring such that for each gene the highest signal intensity obtains value $100 \%$ (dark blue) and absence of signal obtains value $0 \%$ (white). (A) Stage specific expression of Arabidopsis U-box genes (top panel) and E2 genes (bottom panel). The stages of development are indicated at the top by depiction of the growth stage [20]. (B) As in A, but organ specific expression of Arabidopsis U-box (top panel) and E2 genes (bottom panel). Organs for which data are included are indicated at the top. The values of the absolute expression levels are not shown. (C) Quantitative real-time PCR analysis of E3 (U-box) and E2 (UBC) gene expression in rosette leaves. Gene transcript levels were normalized against Actin2 using Q-gene sotftware and methods [27], and each value is the mean from triplicate testing. E3 (U-box) (left panel) and E2 (UBC) (middle and right panels) gene expression levels are shown with different scales. Error bars are standard errors. 
Figure 4 Affinity purified recombinant ubiquitin-conjugating enzyme E2 and ubiquitin-protein ligase $\mathrm{E} 3$ proteins

SDS/PAGE analysis and Coomassie Blue staining of (A) gel molecular mass markers (molecular masses indicated in $\mathrm{kDa}$ at the left) (lane 1), approximately $5 \mu \mathrm{g}$ affinity purified recombinant His6-At2g16740(UBC4/5) (lane 2); His6-At1g78870(UBC13) (lane 3), His6-At5g62540(UBC2) (lane 4); His6-At2g42990 (lane 5); His6-At3g46460(UBC7)

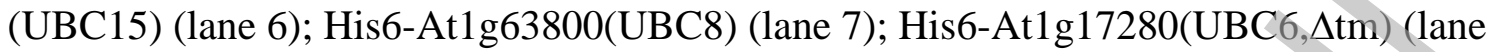
8); His6-At1g16890(UBC13) (lane 9); His6-At5g05080(UBCE) (lane 10); His6At5g53300-UBC4/5 (lane 11) (B) molecular mass markers (molecular masses indicated in $\mathrm{kDa}$ at the left) (lane 1), approximately $5 \mu \mathrm{g}$ purified recombinant $\mathrm{MBP}$ AtPUB63(170-257) (lane 2); MBP-AtPUB14(249-632) (lane 3); His6-MBP-AtPUB54(1308) (lane 4); His6-MBP-AtPUB56(1-365) (lane 5); His6-His6-AtPUB49(1-595) (lane 6); His6-MBP-AtPUB60(1-537) (lane 7); His6-AtPUB41(1-559) (lane 8).

Figure 5 E3 ubiquitination activiy of AtPUB14, AtPUB41, AtPUB49, AtPUB54, AtPUB56, AtPUB60, and AtPUB63 recombinant proteins For the complete reaction, the recombinant version of the Arabidopsis E3 protein as indicated was incubated for two h at $30^{\circ} \mathrm{C}$ in the presence of rabbit $\mathrm{E} 1$, the recombinant Arabidopsis E2 as indicated, ATP, and ubiquitin, and approximately $20 \mu \mathrm{g}$ protein was loaded on a gel and subjected to immonoblotting using an anti-ubiquitin antibody. (A) Reactions with the Arabidopsis E2 as indicated, but without an E3. The Arabidopsis E2 proteins were: His6-At5g05080(UBCE) (lane 1); His6-At5g62540(UBC2) (lane 2), His6At1g63800(UBC8) (lane 3); His6-At2g16740-UBC4/5 (lane 4); His6-At5g53300UBC4/5 (lane 5); His6-At1g17280(UBC6, $\triangle \mathrm{tm}$ ) (lane 6); His6-At3g46460(UBC7) (lane 7); His6-At2g4299(UBC15) (lane 8); His6-At1g78870(UBC13) (lane 9); His6At1g16890(UBC13) (lane 10); no E2 (lane 11). (B) Complete reactions using His6-MBPAtPUB56(1-365) as E3. The E2 in each reaction of lanes 1-7 was as shown in lanes 4-11 in A. (C) Complete reactions as in B but using His6-MBP-AtPUB54(1-308) as E3. (D) Complete reactions using His6-At2g16740-UBC4/5 (lanes 1-3), His6-At5g53300UBC4/5 (lanes 4-6), His6-At1g78870(UBC13) (lanes 7-9) or His6-At1g16890(UBC13) (lane 10-12) as E2 and His6-MBP-AtPUB54(1-308) (lane 1,4,7,10), His6-MBPAtPUB54(1-308,Trp ${ }^{266} \rightarrow$ Ala) (lane 2,5,8,11), or His6-MBP-AtPUB54(1-308, $\operatorname{Trp}^{266} \rightarrow$ HisAla) (lanes 3,6,9,12) as E3. (E) Complete reactions as in B but using MBPAtPUB14(249-632) as E3. (F) Complete reactions as in B but using His6-MBPAtPUB41(1-559) as E3. (G) Complete reactions as in B but using His6-MBPAtPUB60(1-537) as E3. (H) Complete reactions as in B but using MBP-AtPUB63(170257) as E3. The E2 in each reaction was as shown in A. (I) Complete reactions as in B but using His6-AtPUB49(1-595) as E3. The E2 in each reaction was as shown in A. Each result is representative of at least triplicate assays performed with different preparations of E2 and E3 proteins.

Figure 6 Alignment of the sequence of the cyclophilin-like domain of AtPUB49 with other cyclophilin sequences

Alignment of the sequence of the cyclophilin-like domain of AtPUB49 with the complete sequence of cyclophilin A from Homo sapiens (HsCypA; accession code P62937) and the cyclophilin-like domain of the U-box/cyclophilin-like protein of human CYC4 (accession 
code U37219). Residues of importance for the peptidyl-prolyl isomerase activity of HsCypA are shown by a star [40].

Figure 7 Cis-trans peptidyl-prolyl isomerase activity of recombinant AtPUB49 PPIase enzymatic activity of purified recombinant AtPUB49, His6-AtPUB49(1-595), was analyzed using a chymotrypsin-coupled assay. (Main plot) Representative curves showing increase in absorbance over time as an indication of PPIase activity. The formation of p-nitroaniline was determined in the absence of His6-AtPUB49(1-595) (x), or in the presence of $5 \mathrm{nM}(\square), 50 \mathrm{nM}(\mathrm{o}), 150 \mathrm{nM}(\Delta)$, and $250 \mathrm{nM}(+)$ of His6AtPUB49(1-595). (Inserted plot) Concentration-dependence of PPIase activity of His6AtPUB49(1-595). The assay was repeated without and with different concentrations of enzyme (5 nM, $30 \mathrm{nM}$, and $50 \mathrm{nM}$ ), and the rate calculated as described in MATERIALS AND METHODS. An activity of $4.4 \mu \mathrm{mol} \cdot \mathrm{min}^{-1} \cdot \mathrm{mg}^{-1}$ was calculated for His6AtPUB49(1-595). The results are representative of three series of measurements performed with different preparations of His6-AtPUB49(1-595).

\section{Figure 8 Influence of recombinant AtPUB49 on thermally induced aggregation of} Citrate Synthase

A $2 \mu \mathrm{M}$ Citrate Synthase sample was incubated at $43^{\circ} \mathrm{C}$ in $40 \mathrm{mM}$ Hepes ( $\mathrm{pH} 7.5$ ) over $30 \mathrm{~min}$. Aggregation was monitored by measuring the turbidity at $360 \mathrm{~nm}$. The influence of His6-AtPUB49(1-595) on the aggregation of thermally denatured citrate synthase was monitored in the absence $(+)$ or presence of $0.75 \mu \mathrm{M}(\mathrm{x}), 1.50 \mu \mathrm{M}(\mathrm{o}), 3.0 \mu \mathrm{M}(\Delta), 6.0$ $\mu \mathrm{M}(\square)$, and $18 \mu \mathrm{M}(\diamond)$ His6-AtPUB49(1-595). The results are representative of three series of measurements performed with different preparations of His6-AtPUB49(1-595).

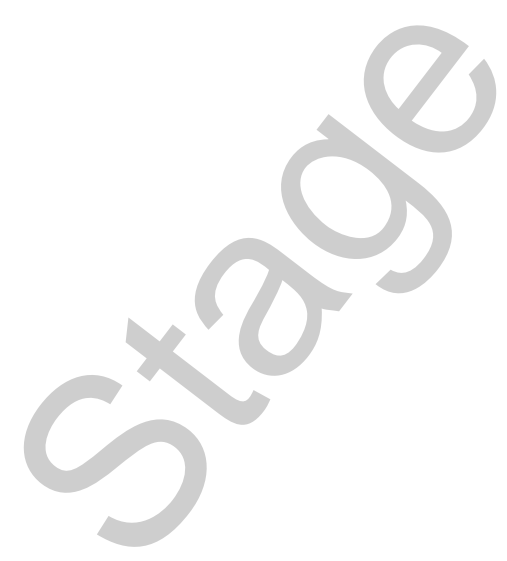




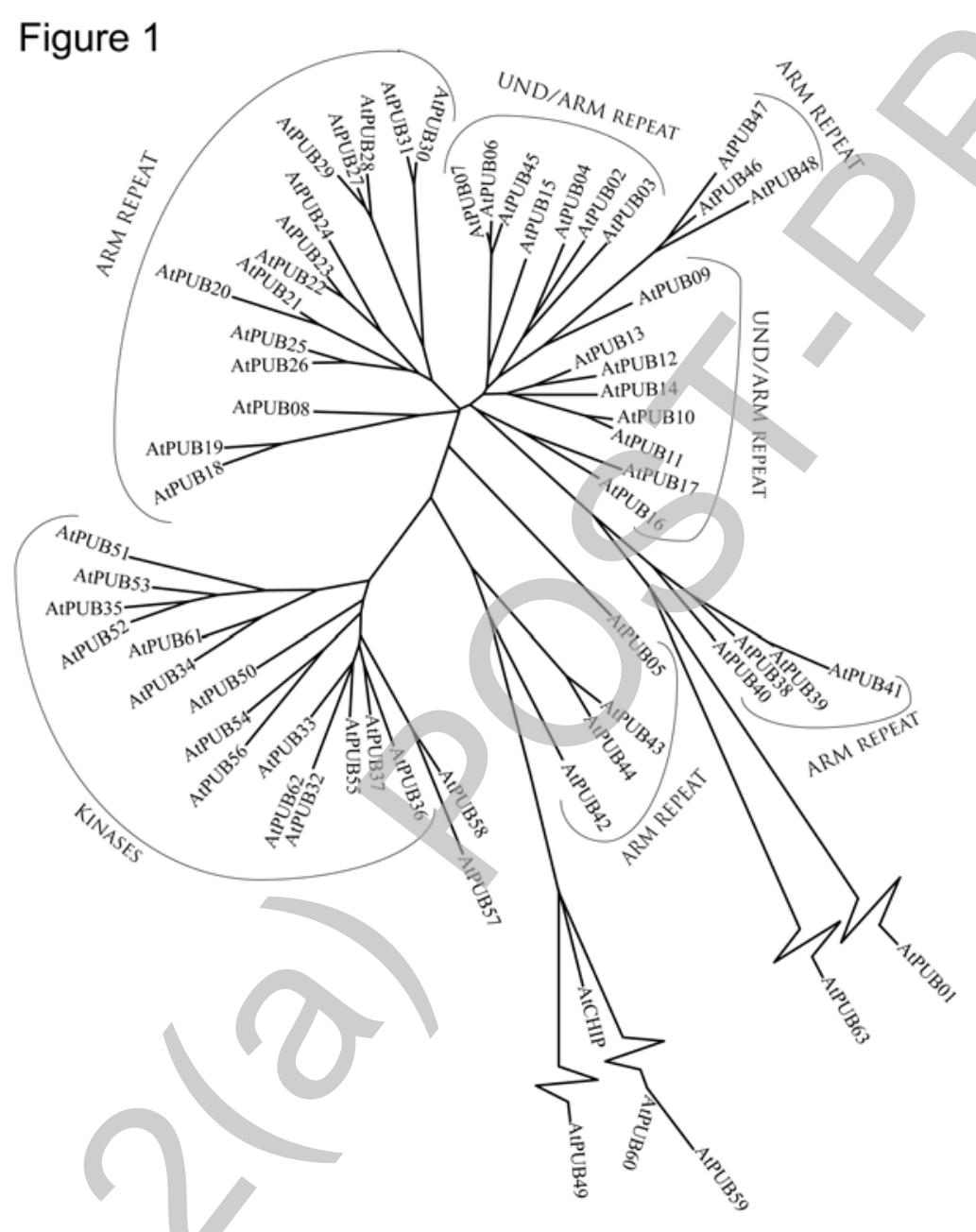


Biochemical Journal Immediate Publication. Published on 07 Apr 2008 as manuscript BJ20071568

Figure 2A

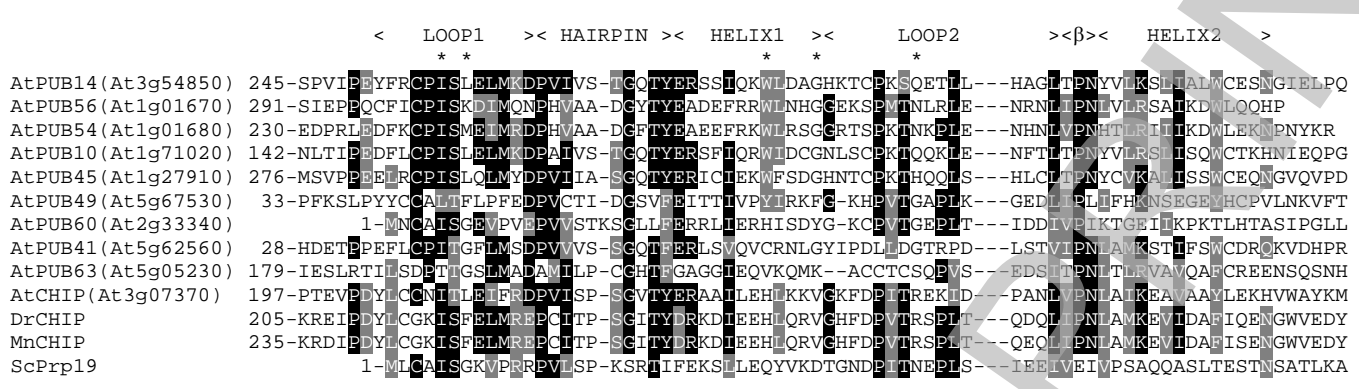

Licenced copy. Copying is not permitted, except with prior permission and as allowed by law. (C) 2008 The Authors Journal compilation (C) 2008 Biochemical Society 
Figure 2B

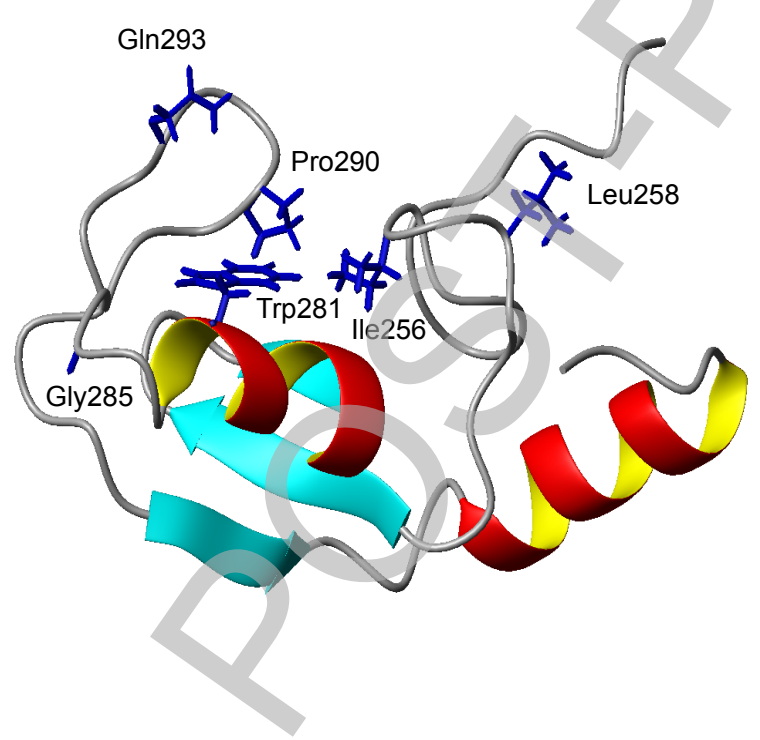

Licenced copy. Copying is not permitted, except with prior permission and as allowed by law. (c) 2008 The Authors Journal compilation (c) 2008 Biochemical Society 


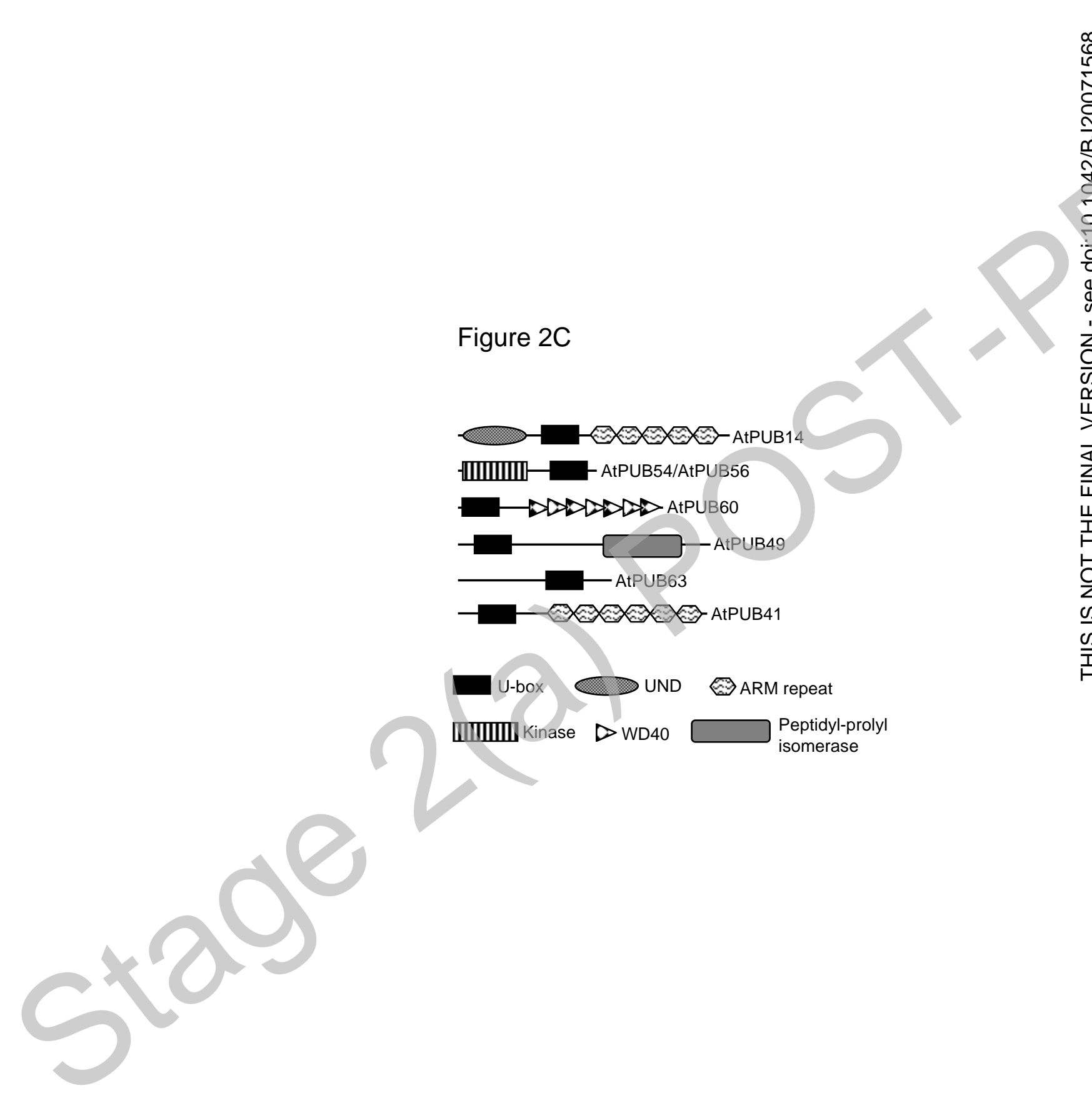


Figure $3 \mathrm{~A}$

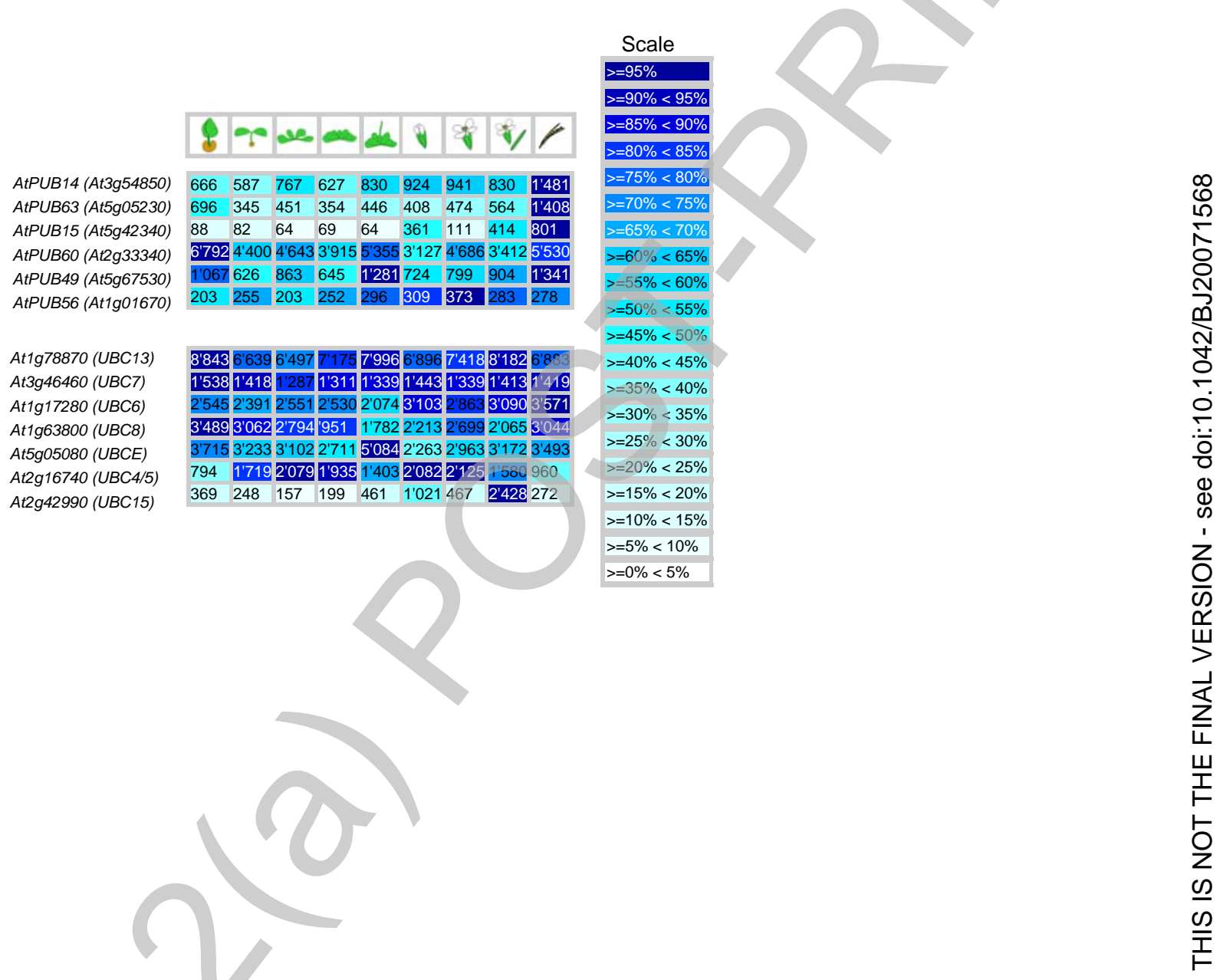

Licenced copy. Copying is not permitted, except with prior permission and as allowed by law.

(c) 2008 The Authors Journal compilation (c) 2008 Biochemical Society 
Figure 3B 
B Biochemical Journal Immediate Publication. Published on 07 Apr 2008 as manuscript BJ20071568

Figure $3 \mathrm{C}$

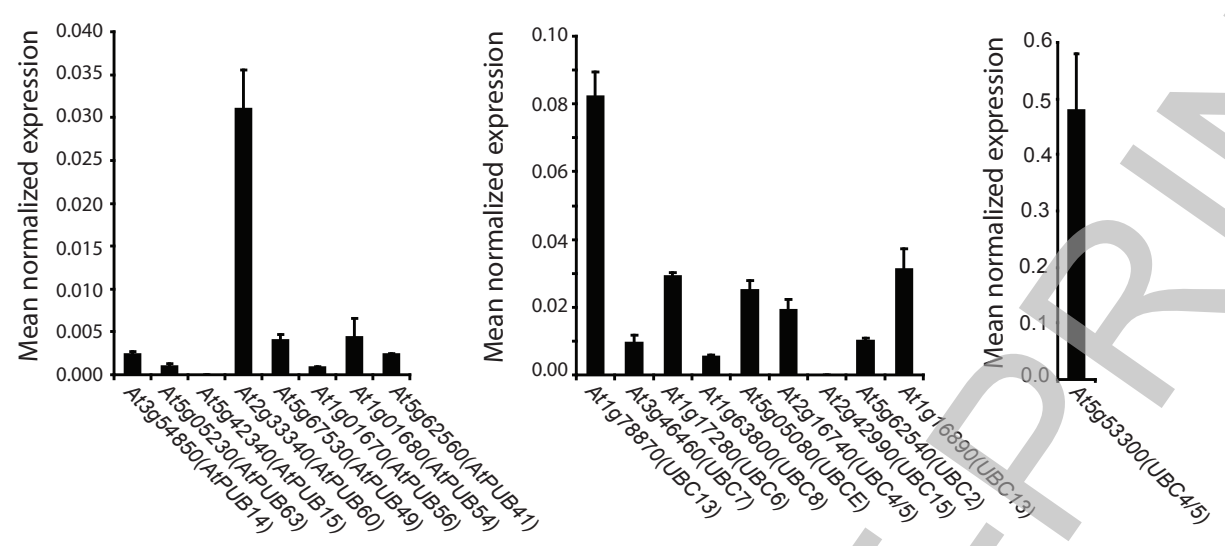


Figure 4

A

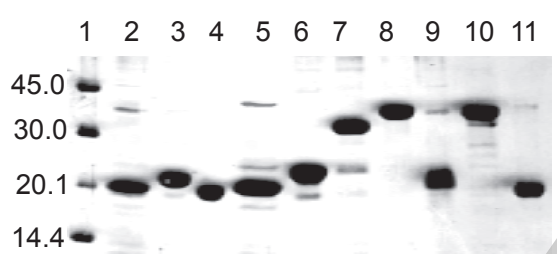

B

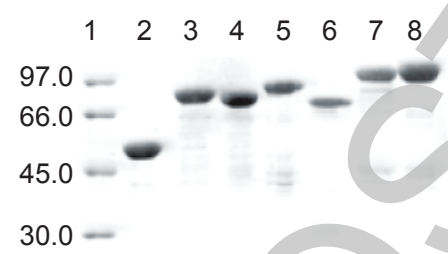

Licenced copy. Copying is not permitted, except with prior permission and as allowed by law. (c) 2008 The Authors Journal compilation (c) 2008 Biochemical Society 


\section{Figure 5}

\section{$5 \mathrm{~A}$}

E3 E2 type

Lane no.
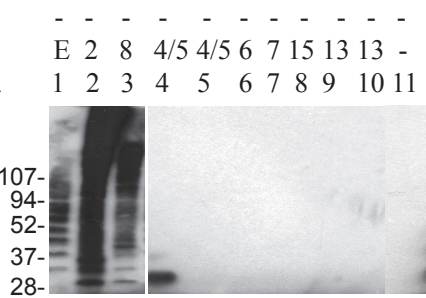

$5 \mathrm{~B}$

E3 His6-MBP-AtPUB56(1-365)

E2 type $\quad 4 / 54 / 567151313$ -

Lane no. $\quad \begin{array}{llllllll}1 & 2 & 3 & 4 & 5 & 6 & 7 & 8\end{array}$

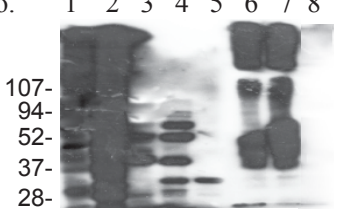

$5 \mathrm{C}$

E3 His6-MBP-AtPUB54(1-308)

E2 type $\quad 4 / 54 / 567151313$.

Lane no. $\quad 1 \quad 2 \quad 3 \quad 4 \quad 5 \quad 6 \quad 7 \quad 8$

\section{$5 \mathrm{D}$}

E3 His6-MBP-AtPUB54(1-308)

Residue 266 W A H W A H W A H W A H

$\begin{array}{lllll}\text { E2 type } & 4 / 5 & 4 / 5 & 13 & 13\end{array}$

Lane no. $\quad \begin{array}{llllllllllll}1 & 2 & 3 & 4 & 5 & 6 & 7 & 8 & 9 & 10 & 11 & 12\end{array}$

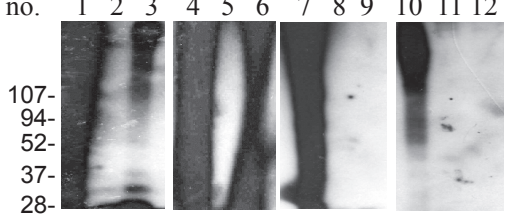

$5 \mathrm{E}$

E3 MBP-AtPUB14(249-632)

E2 type $\quad 4 / 54 / 567151313$ $\begin{array}{lllllllll}\text { Lane no. } & 1 & 2 & 3 & 4 & 5 & 6 & 7 & 8\end{array}$

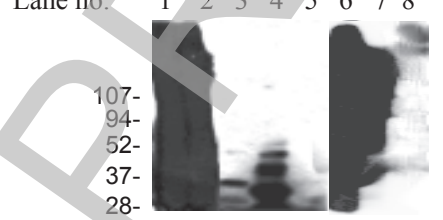

$5 \mathrm{~F}$

E3 His6-MBP-AtPUB41(1-559)

E2 type $\quad 4 / 54 / 567151313$ -

5ane no. $\quad \begin{array}{llllllll}1 & 2 & 3 & 4 & 5 & 6 & 7 & 8\end{array}$
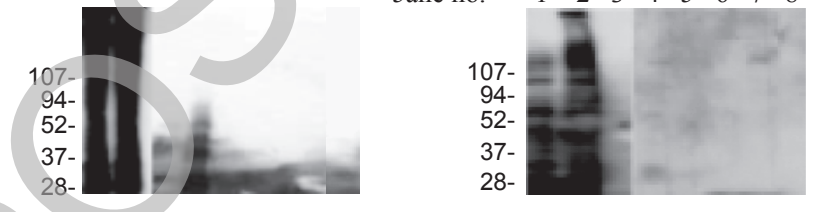

$5 \mathrm{G}$

E3 His6-MBP-AtPUB60(1-537)

E2 type $4 / 54 / 567151313$ -

Lane no. $\quad \begin{array}{llllllll}1 & 2 & 3 & 4 & 5 & 6 & 7 & 8\end{array}$

\section{$5 \mathrm{H}$}

E3 MBP-AtPUB63(170-257)

E2 type 4/5 4/567151313-

Lane no. $\quad \begin{array}{lllllll}1 & 2 & 3 & 4 & 5 & 6 & 78\end{array}$

\section{$5 \mathrm{I}$}

E3 His6-AtPUB49(1-595)

E2 type 4/54/567151313 -

$\begin{array}{lllllllll}\text { Lane no. } & 1 & 2 & 3 & 4 & 5 & 6 & 7 & 8\end{array}$

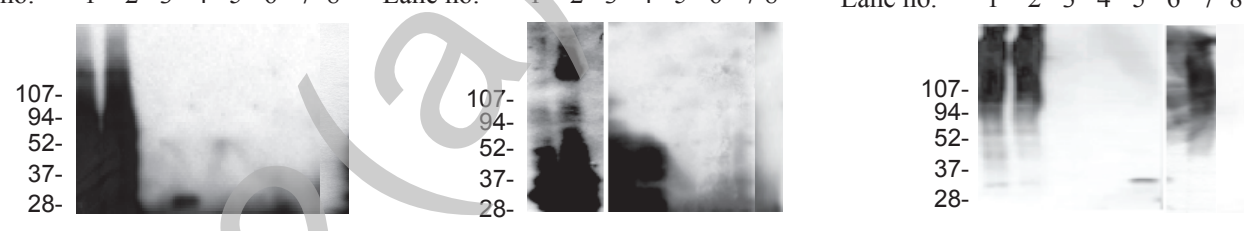


Figure 6

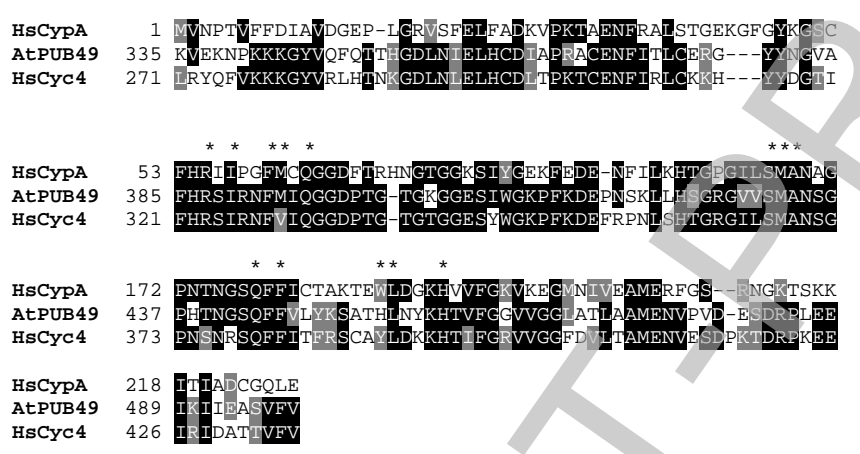




\section{Figure 7}




\section{Figure 8}

